\title{
Literature Survey and Research Agenda of Entry Level Competencies for Private Banking Jobs
}

\author{
Varun Shenoy* \& P. S. Aithal** \\ ${ }^{*}$ College of Management and Commerce, Srinivas University, Mangalore - 575001, \\ Karnataka India. \\ OrcidID: 0000-0001-6564-995X; E-mail: varun_shenoy@rediffmail.com \\ ${ }^{* *}$ Professor, College of Management \& Commerce, Srinivas University, Mangalore, India \\ OrcidID: 0000-0002-4691-8736; E-mail: psaithal@gmail.com
}

Area of the Paper: Business Management.

Type of the Paper: Review Paper.

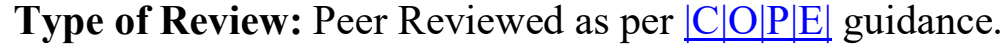

Indexed In: OpenAIRE.

DOI: $\underline{\text { http://doi.org/10.5281/zenodo.4088068. }}$

Google Scholar Citation: IJCSBE.

\section{How to Cite this Paper:}

Varun Shenoy \& Aithal, P. S. (2020). Literature Survey and Research Agenda of Entry Level Competencies for Private Banking Jobs. International Journal of Case Studies in Business, IT, and Education (IJCSBE), 4(2), 176-192. DOI: http://doi.org/zenodo.4088068.

International Journal of Case Studies in Business, IT and Education (IJCSBE)

A Refereed International Journal of Srinivas University, India.

(C) With Authors.

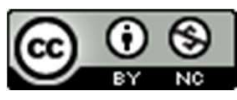

This work is licensed under a Creative Commons Attribution Non-Commercial 4.0 International License subject to proper citation to the publication source of the work.

Disclaimer: The scholarly papers as reviewed and published by the Srinivas Publications (S.P.), India are the views and opinions of their respective authors and are not the views or opinions of the S.P. The S.P. disclaims of any harm or loss caused due to the published content to any party. 


\title{
Literature Survey and Research Agenda of Entry Level Competencies for Private Banking Jobs
}

\author{
Varun Shenoy* \& P. S. Aithal** \\ ${ }^{*}$ College of Management and Commerce, Srinivas University, Mangalore - 575001, \\ Karnataka India. \\ OrcidID: 0000-0001-6564-995X; E-mail: varun shenoy@rediffmail.com \\ ${ }^{* *}$ Professor, College of Management \& Commerce, Srinivas University, Mangalore, India \\ OrcidID: 0000-0002-4691-8736; E-mail: psaithal@,gmail.com
}

\begin{abstract}
Skills are a set of capabilities and behaviours that are necessary for performing a job or task. For every profession aspiring graduate fresh out of college, possessing employability skills is an essential part of being able to meet the challenges of career sustenance in a competitive world. Private Sector banks are also among one of the popular choices for a white collar and high paying jobs among graduates fresh out of campuses. Therefore, the objective of this study is to examine and evaluate the different research studies published on essential skills and competencies necessitated for performing various banking tasks and jobs, especially at the private sector. In this paper, the resultant outcomes based on literature investigation are discussed in detail through a systematic review. The research gap and research agenda for further study are identified and analysed using SWOT and ABCD frameworks. Accordingly, the outcomes post the literature investigation is evaluated by making suggestions to develop a systematic research project relevant to the private sector banking industry job skills and employability.
\end{abstract}

Keywords: Banking Skills, Private Sector Banking, Banking Competencies, Entry Level Jobs, Private Banking Competencies

\section{INTRODUCTION :}

Since Liberalization of India's economy, Private Sector banks have established new practices of service and invented high standards of efficiencies for prospering their stakeholders. Private sector banks have become progressively pioneer in size, customer foundation, service quality, customer options and preferences over years. Private sector banks through their effective customer service and corporate management were even able to post profits at a higher rate compared to public sector commercial banks [1-3]. Private Sector Banking follows recruitment and selection, where there is well elucidated recruitment and selection methodologies followed, participation from business managers and human resources executives' participation in recruitment and selection system plus adopts a transparent direct apt and standardized test used in the hiring process of employees [4]. The recruitment process is highly merit based in private sector banks open for all public without caste category reservations employing group discussion, panel and personal interviews along with Artificial Intelligence AI based written assessments with quick results announced through critical evaluation software [5]. This process would naturally deem attractive and quick as compared to cumbersome recruitment procedure of public sector banks with reservations. Public Sector Banks depend upon the results from common written exams conducted by Institute of Banking and Personal Selection involving rigid stages and scattered timelines for the declaration of results followed by interviews and postings [6-7]. Also, Public Sector Banks cannot conduct Graduate Campus Recruitment directly based on court judgment as it contravenes Competition Law [8]. Therefore, with all light to Indian private banks and to guide and direct the banking job aspiring graduates in private sector to secure an employment, this survey attempts to search and bring out the competencies and skills that are necessary to pursue a career in private banking industry. Competency refers to knowledgeable wisdom, skill, knack, attitude, technique, exposure, dexterity, and attributes that ensures workers in accomplishment of their tasks involving people, money, 
materials and established system at work, college campus, home, or community. The notion of competency has unique understandings and realizes to stay one of the very significant terms in the literature. Competencies, which are most useful for entry level job seeking candidates, mainly include efficient leadership, abilities of predicament-solving, interaction skills, client-inclination, outcomebased, and group work inclination [9]. Relationship between employment skills and work performance aims on the nexus between industrial activities and employees, strategies and customer values followed by service deliveries [10-11]. For the benefit of manpower allocation to work, various techniques in the growth of skill frameworks like singular-work task, single-measurement-suits-everyone, and dual works approaches are discussed [12]. Therefore, scenario strongly denotes that enterprises largely succeed at deploying competencies allot a larger slab of their resources towards alignment of skill benchmarks with plans to combining on to routine compliances which private sector banking has innovated in their hiring processes. Moreover, competitive HR groups of private sector banks utilize change management policies to ensure dynamic behavioural requirements solicited from candidates and effected over period to ensure them as staff and operation of the system. Banks and businesses are adopted work from home or remote branch or virtual banking for survival measures during corona pandemic [13-14]. New Job Seekers must sharpen their preparation and suitability skill sets to mix with Industry 4.0 working environment. However, the graduates experienced online classes and virtual experiences through remote study during the COVID 19 pandemic [15]. Psychologically, skills and competencies are generated from experiences.

\section{OBJECTIVES OF SCHOLARLY REVIEW :}

This study is primarily taken up to determine the various assortment of skills required to perform banking jobs in competitive set up oriented private sector. Secondly, the survey is carried out to present and distinct the various types of review papers that can cater to the private banking skills knowledge base. The aim is also to evaluate the literature published with current banking industry competencies. The Study is also undertaken to present the current banking skills for private sector, know the outlook for competencies in the sector as well as advises for key areas in time especially post corona pandemic world. The Outcome of this review is expected to support towards development of a competency framework for empirical research and testing of the authors.

\section{RESEARCH METHODOLOGY OF LITERATURE REVIEW :}

Research Articles for the study were referred from Google Scholar, Microsoft Academic, IDEAS RePEc, MPRA, SSRN, Research Gate, Academia, and other such resources from the world wide web internet.

Articles resulted from the search of above resources based on research statement, were identified, and referred for review through conducting two primary approaches of Literature Survey. Firstly, approach was synthesized towards the existent literature in research article and assisted to identifies the knowledge as well as gaps in proposed study. Theoretical Basics for the study proposed was extracted to brief the presence of the study statement, justifying the survey as most that caters to something new to the accumulated knowledge, as well as verify the methods and understandings for the study propagated [16-18].

The second pattern of literature review, which focused on chapters of the research article, constituted an authentic and meritous research works [19-21]. Belief is, this approach manifests a gentle beginning for all stakeholders of the field focused in an area along with providing a base for authors.

\section{SCHOLARLY REVIEW OF RESEARCH LITERATURE RELATED TO ENTRY LEVEL COMPETENCIES FOR PRIVATE BANKING JOBS :}

Most of the competencies to perform banking jobs at financial sector comes with experience and training. Communication is a requested skill as it helps the employs to maintain relationships effectively with colleagues and clients [22]. A fresh job seeker for a bank should realize competencies are mapped to overall attributes, competencies with knowledge necessary to execute a banking task in work description and must sharpen the skill [23]. Competencies are required for confidence boost of employees for job delivery and sustained career. In the age of cutthroat contests, banks have begun giving focus towards attraction and retention of talented employees based on their skills by advancing them different career development options with good salary raise in their careers [24]. Technology and 
Technical Skills have gone on to become a must have for young graduate freshers to enter the market [25-27]. Crisis and Disaster response mindset and handling elements are also expected at Banks considering the nature and sensitivity of risk in financial sector. The new employees must match to the Volatility, Uncertainty, Complexity and Ambiguous nature of industry. [28]. Career Networking and Community building among finance professional should also be developed for innovating opportunities to succeed in banking sectors. Networking skills can get a job for an entry level in the banking sector through employee referral. Candidates can use personal contacts who has their relatives working for Private Bank [29-30]. The entry level aspirants should also equip with knowledge of various banking regulations, laws, and policies for a better ethical working in conditions [31].

Related Studies that aimed primary on the competencies sought from new candidate recruitment, applicants have focused on competencies required from fresh candidates of particular academic courses, such as commerce and business [32-33], economics [34], accounting [35-36], engineering [37], operations research [38], and veterinary [39] program courses. A certain number of candidates have focused on skill sets necessary in industries, business or occupations, such as production and manufacturing [40], knowledgebased industries [41], and accounting domain [42].

Studies on new fresher candidates needs of employers also concentrate on the qualities employers seek rather than the skills fresh graduates possess. These qualities mostly include personality characteristics [43-47], degrees earned, attitudes, extracurricular activities, grades [48-52], knowledge in various areas [53-54], previous work experience and the status of graduate applicant's studied Institution [55-57].

The competencies and abilities expected from fresh business management and commerce candidates in general consisting group of practitioners of banks, investment and allied businesses was researched by Rassuli et al. (2012) [32]. It concluded Risk Management and Project Administration being the skills being valued top by the executives. studied Skill Sets essential for graduates in Nigeria was researched by Adebakin et al. (2015), whose samples consisted of bank managers and three other industries [58]. Sodhi and Son (2008) studied analyzing competencies essential in operations, modelling, programming, and statistics for job by candidates [38]. Thus, competencies recruiters seek from fresh graduates include communication skills (Jackling and De Lange 2009 [35]; Sodhi and Son 2008 [38]; Norwood and Henneberry 2006 [43]; Kavanagh and Drennan 2008 [50]; Kirk and Chapman 1992 [51]; Thomas and Nicita 2003 [54]; Andrews and Higson 2008 [55]; Morley and Ayns- ley 2007 [57]; Hesketh 2000 [59]), team-work (Jackling and De Lange 2009 [35]; Thomas and Nicita 2003 [54]; Andrews and Higson 2008 [55]; Morley and Ayns- ley 2007 [57]; Hesketh 2000 [59]), and communicative abilities (Tanyel et al. 1999[33], Hellier et al. 2004 [34]; Husain et al. 2010 [37]; Morley and Aynsley 2007 [57]), which are professional, people handling skills. Universal ski1ls that many recruiters seek involve analytical thought processing (Andrews and Higson 2008 [55]), issues-closing abilities (Hesketh 2000 [59]), comprehension, administration, numerical or quantitative skills (Hesketh 2000) [59], written communications (Hellier et al. 2004 [34]; Thomas and Nicita 2003 [54]), information interpretation (Hellier et al. 2004) [34], Computers and IT (Andrews and Higson 2008 [55]; Hesketh 2000 [59]), decision-taking competencies (Kavanagh and Drennan 2008) [50], along with management of time (Tanyel et al. 1999) [33].

Recent study outcomes show that employer's merit certain skills over the rest. Collet et al. (2015) researched competencies essential of freshers in research sector utilizing a managers' sample and saw a divide between the competencies enterprises need and actual that the candidates possess [41]. Study found that for graduates to match on into the organizational environment, plans, and structures, that suit has to be relative of mental and individual competencies. Ngoo et al. (2015) researched the phenomenon with Malaysian employers and observed that, amongst the set of functional competencies submitted, the most primary skills recruiters expected in accountancy candidates were communication skills, rational thinking abilities, and predicament-solving abilities [36]. Adebakin et al. (2015) observed competencies deem essential by Nigerian employer sample finding that the main essential competencies are ICT, teamworking, decision-making skills, and analytical with predicament-solving competencies [58]. The entry level candidates' competencies recruiters rated low are teamworking, management of risk, leading skills, and deciding abilities of freshers. McMurray et al. (2016) researched the entry level candidates' competency needs with Scottish recruiter sample employers and observed that the prime essential competencies recruiters expected in fresh business management candidates were verbal interaction abilities, flexibility skills, group-working and personal dealing 
abilities. Recruiters felt that regions required primarily to be touched upon in respect of freshers' competencies are verbal interaction needs, groupwork skills, Numerical, Quantitative abilities, followed by language skills.

Hence, recruiters seek inclusive skills from fresh graduate candidates and the main current study outcomes have depicted that the main significant competencies for recruiters are interaction abilities (McMurray et al. 2016 [49] ; Ngoo et al. 2015 [36]) ; Team-Work (Adebakin et al. 2015 [58]; McMurray et al. 2016 [49]); Mental, Cognitive, Inter-personal and Intra-personal Competencies (Collet et al. 2015 [41]); Rational Thought and Predicament Clearing (Ngoo et al. 2015 [36]); ICT, Decision-Taking Abilities, Analytical, and Incident-Solving (Adebakin et al. 2015 [58]); and Inter-personal and Flexibility (McMurray et al. 2016 [49]). Moreover, in banking sector the emphasis was laid out more on the maturity, skills, and entrepreneurial abilities of Bank Managers [60]. Zayas-Ortiz et al. 2015 also spoke about Organizational Commitment and Citizenship Behavior being important among Private Banking Employees [61]. Kaura (2011) was also reflected the need of emotional intelligence among bank employees to handle financial affairs [62].

During 1970s, a Harvard University Professor, McClelland (1973), put forward the concept of competency used to gauge orthodox parameter of evaluation which had stressed cognitive and intelligence assessment in the higher education sector [63]. McClelland's research facilitated a conceptual model that contributed to many further researches at various areas like teaching, skill studies, trade and commerce, and HRM (Spencer \& Spencer, 1993) [64]. Hoffmann (1999) examined historical research studies and emphasized 3 main ideas in elucidating a Skill : (1) qualifications inherent and personal traits, (2) observable behaviours, and (3) self-performance standard results [65]. Prastacos \& Gregory (2012) bought a brief interpretation of skill applications in areas of banking and its effects. Paper also found skills needed and growing skill regions like inter-personal capabilities, decision taking abilities at and during pressure, deal administration, manpower handlings in the banking sector [66].

Table 1 : Key List of Related Scholarly works undertaken on Competency, Entry Level Skills necessitated by Fresh Graduates for Banking Sector :

\begin{tabular}{|c|c|c|c|}
\hline S. NO. & Research Area & Research Focus & Reference \\
\hline 1. & $\begin{array}{l}\text { Competencies for Banking } \\
\text { Industry }\end{array}$ & $\begin{array}{l}\text { Managerial Skills in } \\
\text { the Banking Industry }\end{array}$ & $\begin{array}{l}\text { Pandey, R., et al. } \\
\text { (2015). [67] }\end{array}$ \\
\hline 2. & $\begin{array}{c}\text { Managerial Skills \& } \\
\text { Competencies for Banking }\end{array}$ & $\begin{array}{c}\text { Emotional Intellect of } \\
\text { Managers in the } \\
\text { Banking Industry }\end{array}$ & $\begin{array}{l}\text { Kappagoda, U. W. } \\
\text { M. R. (2013). [68] }\end{array}$ \\
\hline 3. & $\begin{array}{c}\text { Managerial Skills \& } \\
\text { Competencies for Banking }\end{array}$ & $\begin{array}{l}\text { Competencies of } \\
\text { Sales Manager in } \\
\text { Banking Sector }\end{array}$ & $\begin{array}{l}\text { Nhung, D. T. H. } \\
\text { (2019). [69] }\end{array}$ \\
\hline 4. & Banking Skills & $\begin{array}{l}\text { Digital Competencies } \\
\text { in Banking Sector }\end{array}$ & $\begin{array}{c}\text { Jenkin, N., et al. } \\
(2019) .[70]\end{array}$ \\
\hline 5. & $\begin{array}{c}\text { Banking Skills, Entry Level } \\
\text { Graduate Skills }\end{array}$ & $\begin{array}{c}\text { Skill Gap of Business } \\
\text { Graduates in Banking } \\
\text { Industry }\end{array}$ & $\begin{array}{l}\text { Abbasi, F.K., et al. } \\
\text { (2018). [71] }\end{array}$ \\
\hline 6. & $\begin{array}{c}\text { Graduate Competencies in } \\
\text { Banking Sector }\end{array}$ & $\begin{array}{l}\text { Banking Industry } \\
\text { requirements of } \\
\text { Accounting } \\
\text { Graduates }\end{array}$ & $\begin{array}{l}\text { Onumah, J. M., et al. } \\
\text { (2012). [72] }\end{array}$ \\
\hline 7. & $\begin{array}{c}\text { Entry Level Recruitment for } \\
\text { Banking }\end{array}$ & $\begin{array}{l}\text { Make entry-level } \\
\text { hiring an asset }\end{array}$ & $\begin{array}{l}\text { LaBombard, R. J. } \\
\text { (2009). [73] }\end{array}$ \\
\hline 8. & $\begin{array}{l}\text { Entry Level Graduate Skills for } \\
\text { Banking }\end{array}$ & $\begin{array}{c}\text { Graduate } \\
\text { Competency Needs } \\
\text { for Performance in } \\
\text { Banking Industry }\end{array}$ & $\begin{array}{l}\text { Cicekli, E. (2016). } \\
\text { [74] }\end{array}$ \\
\hline
\end{tabular}

Varun Shenoy, et al, (2020); www.srinivaspublication.com 
International Journal of Case Studies in Business, IT, and Education (IJCSBE), ISSN: 2581-6942, Vol. 4, No. 2, October 2020

\begin{tabular}{|c|c|c|c|}
\hline 9. & $\begin{array}{c}\text { Entry Level Graduate Skills for } \\
\text { Banking }\end{array}$ & $\begin{array}{c}\text { Fresh Graduate Skills } \\
\text { for the Banking } \\
\text { Sector }\end{array}$ & $\begin{array}{c}\text { Folcut, O., et al. } \\
\text { (2019). [75] }\end{array}$ \\
\hline 10. & Banking Recruitment & $\begin{array}{c}\text { Using Personal } \\
\text { Contacts and Hiring } \\
\text { in Banking }\end{array}$ & $\begin{array}{c}\text { Fernandez, R. M., et } \\
\text { al. (1997). [76] }\end{array}$ \\
\hline
\end{tabular}

\section{IDENTIFIED ISSUES IN ENTRY LEVEL SKILLS AND COMPETENCIES FOR PRIVATE BANKING SECTOR :}

Review revealed top 5 necessary factors for an entry level job seeker were opportunities for selfdevelopment, career building, sense of recognition and achievement, work environment, and organization that provide training [77]. The Private Banking Sector caters to all these needs in a corporate set-up. Devlin and Peterson (1984) concentrated their studies on elements found essential in initial work by fresh graduates of USA and NZ. Study found graduates' concentration and belief changed over period on Industry [78]. Findings of the study also discovered that the American students, opportunities for progress and self-advancement were ranked on top, followed by challenges and responsibilities, work conditions, and type of job. Meanwhile, the students in New Zealand also toprated chances for progress and self-advancement. Challenge and responsibility, type of job, and training factors were followed. Chacko (1991) found that graduates perceive different excuses that sought them in taking up employment involving cash, status, quotient, standard of living, and the job conditions [79]. Students also believed that academics is the pathway towards the objective of attaining career and professions that they found lucrative. Private Banking Sector recruits directly from campuses and honours freshers' entry level hiring from accounting, commerce, and management backgrounds. Holland (1985) found candidates pick occupations involving conditions matching their interests, desires and loathe [80]. Study also found that accounting major students believed job conditions and professional accountant standard of living suit their self-capabilities, interests plus abilities. Likewise, students hold dream to work in a professional white collared banking environment and accordingly they tend to choose academic courses that offer them suitable placements in banking sector. Keehan (1985) found that graduates indicated specific tastes for careers, training opportunities, free education, and employment security [81]. Thus, various factors believed to be essential for graduates involved cash, status, aptitude, lifestyle, job conditions, power, financial and professional growth, promotions, work location, and job satisfaction. Also, study finds these beliefs changed over period. Choice of academic specialization also determines a significant part in the graduates' career opportunities which private banking offers.

Another important observed issues in banking sector is that Skill sets of bankers bound to change over time except the basic banking skills owing to change in financial environment, generations, and time. Studies have been conducted to determine the competencies and skill gap analysis in the banking sector to understand which skills are efficient for better stakeholder delivery in such a changing circumstance. For instance, it was found at Ernakulam district that there exists a competency skill gaps at delegation, team development, cognitive skills, and administerial competencies of employees at private sector banks [82]. Abbasi et. al (2018) concluded there is a significant gap between skills essentials for banking job and the skills graduates carry learnt or acquired from their colleges or universities [71]. Research found that graduates are specifically lack listening skills, predicament clearing abilities, interaction and leadership skills, inter-personal and cognitive capacities, personality management, quantitative, and rational thought competencies mandatory at banking sector. This Research is based on average scores ranking significance of professional competencies evidencing that hearing, transactional and interaction competencies are very essential competencies for freshers to work in banks. Nithyavathi and Radha (2014) [22] also identified the existence of such skills in Indian Banking Industry and observed that HRD Departments of Banks need to spear forward to nurture these skills for an efficient flow of banking operations by employees [84]. Pandey and Misra (2015) also identified managerial competencies in the banking sector [67]. Author identified around 72 managerial competencies essential in Indian Banking Sector which entry level managers take note of. Those are Technical expertise, Financial management, 
Computing, Strategic thinking, Business expertise, Business process improvement, Negotiation, Quality focused, Customer relations knowledge, Vision, Safety conscious, Following processes \& procedures, Planning \& organizing, Controlling \& Co-ordinating, Change handling skills, Cost conscious, Benchmarking, Crisis management, External awareness, Thinking globally, Ethical/ legal issues, Resource allocation, Navigating the organisation, Task focus, Critical thinking, Maintaining professional \& ethical standards in the work environment, Problem solving, Analysing information \& reducing information overload, Turns negative situation into a positive/ learning situation, Managing knowledge \& talent, Team building, Developing subordinates, Goal setting, Reviewing and guiding, Delegating effectively, Mentoring/ Coaching, Holds self-accountable for actions, Holds others accountable for their decisions, Participative decision making, Autonomy and empowerment, Cultivating climate of trust ,Shows accessibility/ approachability, Feedback, praise and recognition, Managing diversity, Consulting/ facilitating, Co-operation, Communication skills, Listening skills, Understanding self and others, Relationship management, Motivating others, Develops rapport, Achievement orientation, Taking Initiative, Conflict Resolution, Time management ability, Stress management ability, Self-development, Resilience, Hard worker/ Diligent, Humour, Portraying enthusiasm, work commitment, passion \& confidence, Responsible \& dependable, Humility, Consistent, Tolerant, Flexible, Credibility, Assertiveness, Ambitious, Orderliness, and Patience.

\section{IDEAL SOLUTION AND PRESENT STATUS :}

Bresfelean et al. 2010, also identified Competencies and Online Recruiting for Banking Occupations. This research bought out functional banking competency types like ideal execution of rules and legal regulations in the long term, compliance with safety policies, proactive communication in the workplace to execute fundamental operations, basic computer competencies, verification and following the methodologies of interest calculations, fees and commission, practicing the way of settlement operations, release of documents, bank image promotion, customer demand test for bank products, customer relationships, settlement documents acceptance, statement issues, banking services and products, customer complaint resolution and customer requests [85]. Jain (2010) brought out survival skills for new graduates in Banking Sector [86]. These include quantitative skills, professional language, and cultural awareness, client needs and relationship management competencies, IT, Industry and Product Know-how, interpersonal, and entrepreneurial skills, and managerial competencies for longterm sustenance. Bowden et al. (2002) attributed these competencies, qualities, and knowhows university-student engagements should build during their time with the academics [87]. Hence, the entry level graduated should inculcate employability skills for the sector of their choice at their time at college. Chew (2005), advanced views that English language is necessary in the area of banking sector on industry environmental basis for any new entrants to banking [88]. Rahayu and Anna (2013) bought out the importance of soft skills in banking related accounting, commerce and management studies graduates undertake stating effective soft skills is the key for success in banking [89-90]. Badmapriya and Harihara (2012) also propagated sustenance skills for business management graduates required in Banking. Those survival skills in Banking Job included communication skills, group working, adaptability and responsibility, interaction and networking competencies, initiation and customer orientation, appearance and perseverance, operations skill, creativity and problem-solving skills, job performance and tech savviness [91]. Serrano (2019) in his conceptual framework suggested that a good combination of employability indices such as reading skills, math skills, communication skills, computer application, decision making skills, work ethics and personality among business graduates are significant to banks whether they are universal, commercial or thrift banks. Study found that reading skills, communication skills, computer applications and personality are important employability indices commonly significant to banks from business graduates [92]. Ting and Ying (2012) in their research state Malaysian Banking recruiters regard shrewdness is the most significant skill, followed by oral communications, ethics, care, learning oriented, writing skills, team-player abilities, computer system competencies, value-adding, adaptability with problem-solving and dependable. Also, Malaysian bankers regarded innovation, reporting, evaluating and global knowledge, diversity, researching skills, leadership and mathematical skills as constant in their significance in today's workplace [93]. Hesketh and McLaghlan (1991) found for entry level graduates in banking, career compromises and adjustment come from avenues for desires and use of competencies and capabilities were more essential as a remedy [94].

Varun Shenoy, et al, (2020); www.srinivaspublication.com 
7. SUMMARY OF PRIMARY BANKING SKILLS \& COMPETENCIES IDENTIFIED BASED ON LITERATURE SURVEY :

Following are primary skills essential for performing banking activities especially in private sector considering the nature of their operations :

Table 2 : Conclusive Major Banking Skill Abilities along with their Constituent elements determining the skill structure for banking jobs

\begin{tabular}{|c|c|}
\hline $\begin{array}{c}\text { PRIMARY SKILL SETS } \\
\text { FOR BANKING JOBS }\end{array}$ & $\begin{array}{c}\text { EXPOSITORY COMPONENTS WHILE PERFORMING } \\
\text { THE TASKS }\end{array}$ \\
\hline $\begin{array}{c}\text { INTELLETUAL SKILLS } \\
\text { [74] [75] }\end{array}$ & $\begin{array}{c}\text { CREATIVITY, FORESIGHT, ANALYTICAL REASONING, } \\
\text { APTITUDE }\end{array}$ \\
\hline $\begin{array}{c}\text { SERVICE EFFICIENCY } \\
\text { [74] [93] [96] }\end{array}$ & COMMUNICATION SKILLS, COMMITMENT, \\
TRUSTWORTHINESS, NETWORKING \\
\hline $\begin{array}{c}\text { SELF-EMPOWERMENT } \\
\text { [74] [82] [93] }\end{array}$ & ENTREPRENEURIAL DRIVE, HONESTY, INTEGRITY, \\
DIGNITY AND RESPECT
\end{tabular}

\section{IDENTIFIED RESEARCH GAPS FROM THE REVIEW FOR AUTHOR'S FURTHER STUDY :}

Here, so to conclude from the enlisted banking skills derived from banking skill-based literature review, the skills seems to intersect with the entry level graduates' perceptions and aspiration from their career and employment literature. However, a comprehensive effort to link or align these essential entry level perception and aspirations of fresh job seeker graduates with the above identified banking skills has not been seen in the literature sphere.

To recapitulate, though good number of research (Adebakin et al. 2015 [58]; Al Shayeb 2013 [53]; Andrews and Higson 2008 [55] ; Bachynsky et al. 2013 [39]; Coetzer and Sitlington 2014 [48]; Cook and Finch 1994 [56]; Collet et al. 2015 [41]; Daud et al. 2012 [47]; McMurray et al. 2016 [49]; Hellier et al. 2004 [34]; Husain et al. 2010 [37]; Jackling and De Lange 2009 [35]; Kavanagh and Drennan 2008 [50]; Kirk and Chapman 1992 [51]; Klibi and Oussii 2013 [42]; Morley and Aynsley 2007 [57]; Norwood and Henneberry 2006 [43]; Ngoo et al. 2015 [36]; Rassuli et al. 2012 [32]; Rivera 2011 [52]; Sodhi and Son 2008 [38]; Sullivan 2012 [40]; Tanyel et al. 1999 [33]; Thomas and Nicita 2003 [54]; Shenoy and Aithal 2018 [97-98]) has been made available on recruiters requirements expected from graduate candidates, only handful concentrate on competencies so much as standards or calibre. Select research (Adebakin et al. 2015 [58]; Bachynsky et al. 2013 [39]; Collet et al. 2015 [41]; Hellier et al. 2004 [34]; Husain et al. 2010 [37]; Jackling and De Lange 2009 [35]; Klibi and Oussii 2013 [42]; Ngoo et al. 2015 [36]; Rassuli et al. 2012 [32]; Sodhi and Son 2008 [38]; Sullivan 2012 [40]; Tanyel et al. 1999 [33] focus on the definite competencies recruiters require, however most of these dwell 
towards graduate skills honed from specific academic courses, there have been an academic major concentration. Countable number of studies also evaluate competencies required for a particular occupation and business (Collet et al. 2015 [41]; Klibi and Oussii 2013 [42]; Sullivan 2012 [40], however those transact with the banks (Adebakin et al. 2015 [58]; Cicekli 2015 [74]; Rassuli et al. 2012 [32]) does not either bring out essential competencies but concentrate on wisdom requirements or count the bank sector with many other business areas too. Thus, there is aperture between competencies recruiters in the banks particularly require fresh graduate candidates to possess due to volatile business environment. Necessitation to investigate the problem utilizing further studies for purpose to locate in brief the work-focused and inclusive competencies essential for fresh candidates looking placement in the bank industry for making possible to cater the entry level candidate competency requirements.

Study also find a gap in studies involving a comprehensive blueprint or framework for entry level graduates to follow targeting the banking industry focusing on the competencies required in the banking domain in general both Public and Private Sector Banks for effective placements. Nevertheless, the culpability for realizing HR requirements depends with banking industry than with the varsities or educational institutions as bankers are the practitioners wanting hiring requirements to be fulfilled. Bankers are suggested to liaise with varsities and public officers in education toward facilitation of graduate requirement expectations and execute collaborative programs towards the realization of skill objectives.

\section{RESEARCH AGENDA FOR ENTRY-LEVEL JOB SKILLS DESIRED FOR PRIVATE BANKING SECTOR SPECIFIC STUDY :}

Based on the above studies, primary author has formulated following study agendas for further research that shall benefit graduates and industry:

(1) To recommend 'Skill Competencies' required for job seeking graduates or students to fit and perform at entry level private banking employment interview rounds and jobs.

(2) To build a "Capability Skills Chart", indicating skills required to clear entry level private banking interviews and work in the new age technology enabled Private Banking business \& industry environment for graduate freshers.

(3) To present the "Key Skill Element Composition" of an entry level Private Banking Interview process and career.

(4) To develop a detailed draft "Competency Framework for Entry Level Private Banking Jobs" for serving in selection and sustenance of entry level graduates in Private Banking Sector.

\section{SWOT ANALYSIS OF RESEARCH AGENDA :}

Strength :

(1) The Objective focuses on realizing professional well-trained fresh young manpower to private banks.

(2) The agenda when implemented leads to better interaction of Banking Industry with University Academia for ideal skill placement.

(3) Agenda provides a ready framework for trainers at university levels to teach students of banking skills towards better preparation to clear banking interviews.

(4) Fresh Graduates aspiring for private banking jobs at and after campus can self-study and determine their banking job skills.

Weakness :

(1) The Skill Agenda above is judgemental and time bound.

(2) The Objectives strives towards labour intensive phenomenon involving categorization, recoding, testing, analysis, and interpretations.

(3) Variations in Suitability of the Objectives to Industry Realities and Culture.

(4) Interpretation Differences of the skill agenda to the nature of banking jobs and tasks.

Opportunities :

(1) The Skill Identification Objective also apply to entry-level Public-Sector Banking Jobs.

(2) The Objective will contribute to 'Skill India' Initiative of the Nation. 
(3) Fresh Graduates can explore Banking and Financial Sector Skills conveniently and easily.

(4) Adoptable by relevant stakeholders researching on Skill and Competency Ecosystem.

Threats :

(1) Environmental Changes in Banking Industry and Academic Education System affecting changes to established Skill sets.

(2) Perils of Pandemic on Industry and Academia affecting the agenda.

(3) Replacement of Human Employees at Private Banks with Technology Robots.

(4) Any other new inventions or discoveries or innovations in the field disrupting the execution of agenda.

\section{FINAL RESEARCH PROPOSAL IN CHOSEN TOPIC :}

Considering the above gap in the Research Environment, it has been determined to place the final research proposal as follows :

\section{1. Title :}

Competency Framework

for Entry Level Private Banking Jobs

\section{2. Introduction :}

As observed in the gap above in review and need to support the entry level graduates in Private Banking Sector to achieve career success and better livelihood, study will develop a Comprehensive Framework of Skills applicable to entry level private banking jobs at the end of research. The Study will discuss the Primary Skill Sets and Competencies necessitated by entry level graduates to work in Private Banking Sector. The Main Skill Sets will also be segregated to their critical constituent components to know and understand the breakdown better.

\section{3. Research Objectives :}

(1) To recommend 'Skill Competencies' required for job seeking graduates or students to fit and perform at entry level private banking employment interview rounds and jobs.

(2) To build a "Capability Skills Chart", indicating skills required to clear entry level private banking interviews and work in the new age technology enabled Private Banking business \& industry environment for graduate freshers.

(3) To present the "Key Skill Element Composition" of an entry level Private Banking Interview process and career.

(4) To develop a detailed draft "Competency Framework for Entry Level Private Banking Jobs" for serving in selection and sustenance of entry level graduates in Private Banking Sector.

\section{4. Proposed Methodology :}

Research Population

The Study will be conducted by seeking and soliciting interactions with employees of Private Sector banks across Dakshina Kannada District on their experience and understanding of the skills and practical competencies applied in the branches.

Sample :

This research will be working with finite population above and number of employees at each private bank branches were determined through contact with HR. Hence, a Study Sample from the population will be determined by applying a relevant statistic. The Sample will be a representative of the population.

\section{Instruments :}

The Skill Constructs of the Preliminary Competence Framework will be tested via Questionnaire as well as its critical constituent components will be measured a rating score card.

\section{Study Procedure :}

The Initial built Model based on focus group interaction and literature will be tested and will be modified to add or subtract items based on the outcome for industry suitability and applicability.

Data Analysis and Interpretation :

Data collected from Respondents will be tested using suitable statistical tests and outcomes will be interpreted based on scientific and experiential inferences for better decision making.

11. 5. Results and Findings :

Results and Findings from the outcome will be published through diagrammatic, tabular and figurative representations for scholarly depictions. 


\section{6. Final Conclusion and Implications :}

The conclusion will be given robust and determine to signify the effect of findings to related areas and stakeholders for further study and future research.

\section{7. Research Ambit and Restraints :}

The research is currently focused toward Private Banking Sector who facilitates equality hiring without reservations and follows business corporate culture. For meeting the timeliness of the work, the banks are chosen in and around Dakshina Kannada area of Karnataka. The study will not cover Public Sector Banks owing to difference in their working environment, recruitment methods and service delivery styles. The study is also limited to the focus of entry level fresher graduates from campus or passing out of work for looking for banking jobs. This is to make the study accurate and niche.

\section{ABCD ANALYSIS OF RESEARCH PROPOSAL :}

ABCD analysis was developed by Aithal et al. 2015 as a new model to analyse concepts, phenomena and business models [95]. The analysis also extracts the measurability features of proposals before implementation from various stakeholder perspectives. Accordingly, Fresh Job Seekers or Campus Graduates, University Colleges and Private Banking Industry are identified as the stakeholders in the study proposal to fulfill the gaps.

\section{Advantages to Fresh Job Seekers, Universities, and Industry:}

(1) The Proposal developed above works to bridge the banking job skills gap in Graduate Market and Research Sphere.

(2) The Study Proposal is Universal and is applicable for Public Sector and other banking formats.

(3) The proposal is flexible to incorporate changes in Banking Skill Ecosystem in the course of study.

(4) The Proposal has the potential of studying skill relationship with nature of banking job and its application.

\section{Benefits to Fresh Job Seekers, Universities, and Industry :}

(1) The Proposal leverages Professional Skills and is an agent of Change.

(2) The Study embraces cooperation, collaboration among stakeholders and facilitates University Academia Banking Industry relationship in National Skill Development.

(3) The Proposed Study shall benefit graduates at campus and first job hunters in banking industry by providing a ready reckoner handbook of needed skills.

(4) The framework generated in the proposal will cater as a ready model of training students for private banking jobs at university campuses.

Constraints toward Fresh Job Seekers, Universities, and Industry :

(1) The Proposal is bound by time and is discretionary.

(2) The Study Proposition is limited to Jurisdictions of Dakshina Kannada District.

(3) The research proposal is subject to limitations of accessing the data sources of subjects owing to their occupancies at Bank.

(4) Variations in Industry response to the study proposal.

Disadvantages applicable to Fresh Job Seekers, Universities, and Industry :

(1) Changes in Environmental Factors pose threat toward the causation and effect of proposal.

(2) The Proposal focuses on Private Banking Sector only to draw study samples to match study time of doctoral research.

(3) Pandemic can hamper the implementation of Research Proposal.

(4) The Proposal is susceptible to Study Subjects and Focus Group Bias.

13. SUGGESTIONS TO IMPLEMENT RESEARCH ACTIVITIES ACCORDING TO PROPOSAL :

(1) Choose Study Participants

The Participants for this study are identified as the Private Banking Employees around Dakshina Kannada.

\section{(2) Adopt Suitable Research Methods}

To explore the necessary required skills, EFA Exploratory Factor Analysis would be appertained to learn the factors and elements influencing skills mandatory for entry level private banking jobs.

(3) Conduct Data Collection

Data for the study would be solicited through applicable research instruments such as Questionnaire,

Varun Shenoy, et al, (2020); www.srinivaspublication.com 
Expert Reviews and Focus Group Methods involving study sample.

(4) Execute Data Analysis

Data Analysis would be conducted through applicable statistical tools and tests such as Chi-Square, Regression Analysis and Correlations Tests.

(5) Result Interpretation and Conclusions

Inferences will be advanced based on statistical test outcome, interaction experiences with study subjects for making rational understandings and decisions.

\section{(6) References and Bibliography}

Related literary works and books will be quoted to evidence and solidify the conclusions and suggestions extended from the outcome.

\section{CONCLUSION :}

In terms of fresh graduate skills, previous research results have depicted that, banks seek inclusive competencies from entry level graduates that can be applied in various functions of a bank. Inclusive skills preferably over task-centric competencies which can be inhouse trained once hired. Though research studies have catered whether entry level candidates possess essential competencies for being fluent at these works or not, there is an aperture in extensive studies on this predicament in both Private or Public banking sector. To encounter the requirements of recruiters in the private banking industry, personnel having autonomy, students and educators require to understand what these requirements are as a primer for further research in this area. Lastly, principal aim in this review was to expound the different varieties of literature centric to the employment skills and competencies essential for private banking sector. The descriptive exposition in this paper is expected to serve as a worthy source for administering, assessing, or utilizing appraisals in this significant and surging research area. Aspirations and Perceptions must be aligned with skills or generated out of competencies.

\section{REFERENCES :}

[1] Chaudhary, G. (2014). Performance comparison of private sector banks with the public sector banks in India. International Journal of Emerging Research in Management \& Technology, 3(2), 5-12.

[2] Pawan, Gorav., \& Bhanwar, Singh (2016). Comparative Study on Financial Performance of Selected Indian Private Sector Banks. International Journal of Marketing \& Financial Management, 4(3), 46-60.

[3] Kashappa, L., \& Basavaraj, C. S. (2017). Comparative performance analysis of the ICICI bank and the HDFC bank. The Indian Journal of Commerce, 70(2), 58-64.

[4] Kumari, S. N. R. B., \& Rathiha, D. R. (2017). Employees Perception on Recruitment and Selection Process in Public and Private Sector Banks. International Journal of Management, 8(5), 44-52.

[5] SINDHU, S., \& KAUL, N. (2017). Critical Evaluation of The Recruitment Process of Business Development Executive at Private Sector Bank, Pune. CLEAR International Journal of Research in Commerce \& Management, 8(8), 55-59.

[6] Thorpe, E., \& Thorpe, S (2012). CWE-Clerical Cadre. Dorling Kindersley \& Pearson Education India.

[7] Jha, S. N (2014). GENERAL AWARENESS FOR IBPS, SBI, BANKING EXAMINATIONS. Kalinjar Publications 2015 Edition.

[8] Vuppuluri, Prasanth (2015). Campus Recruitments are Unfair. Economic \& Political Weekly, 50(36), 18-20.

[9] Abraham, S. E., Karns, L. A., Shaw, K., \& Mena, M. A. (2001). Managerial competencies and the managerial performance appraisal process. Journal of Management Development 20(10), 842-852.

[10] Eichinger, B., \& Ulrich, D. (1995). Are you future agile? People and Strategy 18(4), 30-34.

[11] Eichinger, R., \& Ulrich, D. (1997). It's de-ja future all over again: Are you getting ready? People and Strategy, 20(2). 50-55.

[12] Mansfield, R. S. (1996). Building competency models: Approaches for HR professionals. Human 
Resource Management, 35(1), 7-10.

[13] Piller, F. T. (2020). Ten Propositions on the Future of Digital Business Models for Industry 4.0 in the Post-Corona Economy, Platform Industrie 4.0, 1(1), 1-7.

[14] Axis bank to adopt wfh as an integral part of work culture. (2020). www.sightsinplus.com. https://sightsinplus.com/news/jobs-news/axis-bank-to-adopt-wfh-as-an-integral-part-of-workculture/

[15] Crawford, J., Butler-Henderson, K., Rudolph, J., \& Glowatz, M. (2020). COVID-19: 20 Countries' Higher Education Intra-Period Digital Pedagogy Responses. Journal of Applied Teaching and Learning (JALT), 3(1), 1-20.

[16] Sylvester, A., Tate, M., \& Johnstone, D. (2013). Beyond synthesis: Re-presenting heterogeneous research literature. Behaviour \& Information Technology, 32(12), 1199-1215.

[17] Levy, Y., \& Ellis, T. J. (2006). A systems approach to conduct an effective literature review in support of information systems research. Informing Science, 9, 181-212.

[18] Hart, C. (2018). Doing a literature review: Releasing the research imagination. Sage Publications.

[19] Paré, G., Trudel, M. C., Jaana, M., \& Kitsiou, S. (2015). Synthesizing information systems knowledge: A typology of literature reviews. Information \& Management, 52(2), 183-199.

[20] Templier, M., \& Paré, G. (2015). A framework for guiding and evaluating literature reviews. Communications of the Association for Information Systems, 37(1), 6-10.

[21] Mulrow, C. D. (1994). Systematic reviews: rationale for systematic reviews. BMJ, 309(6954), 597599.

[22] Nithyavathi, K., \& Radha, P. (2014). Job Competency of Bank Employees in India (With Special Reference to Coimbatore District). Global Journal for Research Analysis, 1(1), 127-130.

[23] Jeevarekha, R., Hariharan, R. (2018). Competency Mapping in Banking Sector. IJEMR, 8(4), 110.

[24] Akar, A., \& Sharma, G. (2018). An Empirical Study on Different factors of Talent Management Practices influencing the Employees Satisfaction in Banking Sector (With Special Reference to Private Sector Banks). Sumedha Journal of Management, 7(4), 76-85.

[25] Wiedmaier, C. (1998). Computer Competencies Needed for Entry-Level Employment. In Delta Pi Epsilon National Conference Proceedings (Louisville, Kentucky, November 19-21, 1998). Delta Pi Epsilon Society, Little Rock, AR. 11(1), 61-65.

[26] Leipold, J. G. (2013). The new entry-level legal employment market. The Bar Examiner, 82(2), 617.

[27] Crosman, P. (2018). How Artificial Intelligence is reshaping jobs in banking. American Banker, 183(88), 1-5.

[28] Nayak, A. K., \& Majumder, A. (2016). Challenges and Winning Strategies at the Entry Level Jobs in Banking and Financial Services Industry. Parikalpana: KIIT Journal of Management, 12(1), 7786.

[29] Fernandez, R. M., \& Weinberg, N. (1997). Sifting and sorting: Personal contacts and hiring in a retail bank. American Sociological Review, 1(1), 883-902.

[30] Neckerman, K. M., \& Fernandez, R. M. (2003). Keeping a job: Network hiring and turnover in a retail bank. Research in the Sociology of Organizations, 20(1), 299-318.

[31] Lucca, D., Seru, A., \& Trebbi, F. (2014). The revolving door and worker flows in banking regulation. Journal of Monetary Economics, 65(2), 17-32.

[32] Rassuli, A., Bingi, P., Karim, A., \& Chang, O (2012). A survey of critical knowledge and skills of business school graduates: employer perspectives. The Journal of International Management 
Studies, 7(2), 1-6.

[33] Tanyel, F., Mitchell M. A., \& McAlum, H. G. (1999). The skill set for success of new business school graduates: do prospective employers and university faculty agree? Journal of Education for Business, 75(1), 33-37.

[34] Hellier, P., Keneley, M., Carr, R., \& Lynch, B (2004). Towards a market-oriented approach: employer requirements and implications for under-graduate economics programs. Economic Papers, 23(3), 213-233.

[35] Jackling, B., \& De Lange, P (2009). Do accounting graduates' skills meet the expectations of employers? A matter of convergence or divergence. Accounting Education: An International Journal, 18(4), 369-385.

[36] Ngoo, Y. T., Tiong, K. M., \& Pok, W. F. (2015). Bridging the gap of perceived skills between employers and accounting graduates in Malaysia. American Journal of Economics, 5(2), 98-104.

[37] Husain M.Y., Mokhtar S. B., Ahmad A. A., \& Mustapha, R (2010). Importance of employability skills from employers' perspective. Procedia Social and Behavioral Sciences, 7(1), 430-438.

[38] Sodhi, M. S., \& Son, B. G. (2008). ASP, the art and science of practice: skills employers want from operations research graduates, Interfaces, 38(2), 140-146.

[39] Bachynsky, E. A., Dale, V.H.M., Kinnison, T., Gazzard. J., Baillie, S (2013). A survey of the opinions of recent veterinary graduates and employers regarding early career business skills. Veterinary Record, 172(23), 604-609.

[40] Sullivan, D.W. (2012). Manufacturing hiring trends: employers seeking more diverse skills. International Journal of Management \& Information Systems, 16(3), 247-254.

[41] Collet, C., Hine, D., \& du Plessis, K (2015). Employability skills: perspectives from a knowledgeintensive industry. Education + Training 57(5), 532-559.

[42] Klibi, M. F., \& Oussii, A. A.(2013). Skills and attributes needed for success in accounting career: do employers' expectations fit with students' perceptions? Evidence from Tunisia. International Journal of Business and Management 8(8), 118-132.

[43] Norwood, F. B., \& Henneberry, S. R. (2006). Show me the money! The value of college graduate attributes as expressed by employers and perceived by students. American Journal of Agricultural Economics, 88(2), 484-498.

[44] Briggeman, B. C., \& Norwood, F. B. (2011). Employer assessment of the college graduate: What advisors need to know. Journal of Natural Resources and Life Sciences Education, 40(1), 19-28.

[45] Feuz, R., \& Norwood, F. B. (2019). Valuing College Graduate Attributes and Skills: Employer Willingness to Pay as Elicited through Design Valuation. Applied Economics Teaching Resources (AETR), l(1), 14-30.

[46] Adnan, Y. M., Daud, M. N., Alias, A., \& Razali, M. N. (2017). Importance of soft skills for graduates in the real estate programmes in Malaysia. Journal of Surveying, Construction and Property, 3(2), 1-13.

[47] Turiman, P., Omar, J., Daud, A. M., \& Osman, K. (2012). Fostering the 21st century skills through scientific literacy and science process skills. Procedia-Social and Behavioral Sciences, 59(1), 110 116.

[48] Coetzer, A., \& Sitlington, H. (2014). What knowledge, skills and attitudes should strategic HRM students acquire? A Delphi Study. Asia Pacific Journal of Human Resources, 52(2), 155-172.

[49] McMurray, S., Dutton, M., McQuaid, RW., \& Richard, A (2016). Employer demands from Business Graduates. Education + Training, 58(1), 112- 132.

[50] Kavanagh, M. H., \& Drennan, L (2008). What skills and attributes does an accounting graduate need? Evidence from student perceptions and employer expectations. Accounting and Finance, 
48(2), 279-300.

[51] Kirk, C., \& Chapman, R (1992). Science and technology management: designing an undergraduate course. Research in Science Education, 22(1), 255-259.

[52] Rivera, L. A. (2011). Ivies, extracurriculars, and exclusion: elite employers' use of educational credentials. Research in Social Stratification and Mobility, 29(1), 71-90.

[53] Al Shayeb, A. M. (2013). Finance graduates' knowledge and skills development: graduate and employer perceptions in United Arab Emirates. Journal of Education for Business, 88(6), 307313.

[54] Thomas, I., \& Nicita, J (2003). Employers' expectations of graduates of environmental programs: an Australian experience. Applied Environmental Education and Communication, 2(1) 49-59.

[55] Andrews, J., \& Higson, H (2008). Graduate employability, soft skills versus hard business knowledge: a European Study. Higher Education in Europe, 33(4), 411-422.

[56] Cook, E.D., \& Finch, B (1994). Qualities employers seek in new accounting employees. Journal of Education for Business, 69 (3), 136-139.

[57] Morley, L., \& Aynsley, S (2007). Employers, quality and standards in higher education: shared values and vocabularies or elitism and inequalities? Higher Education Quarterly 61(3), 229-249.

[58] Adebakin, A.B., Ajadi, O.T., Subair, S.T. (2015). Required and possessed university graduate employability skills: perceptions of the Nigerian employers. World Journal of Education 5(2), $115-121$.

[59] Hesketh, A. J. (2000). Recruiting an elite? Employers' perceptions of graduate education and training. Journal of Education and Work, 13(3), 245-271.

[60] Avkiran, N. (2000). Interpersonal skills and emotional maturity influence entrepreneurial style of bank managers. Personnel Review, 29(5), 654-675.

[61] Zayas-Ortiz, M., Rosario, E., Marquez, E. \& Gruñeiro, P. (2015). Relationship between organizational commitments and organizational citizenship behaviour in a sample of private banking employees. International Journal of Sociology and Social Policy, 35(1), 91-106.

[62] Kaura, P. (2011). Enormity of emotional intelligence in Indian banking sector. Asia Pacific Journal of Research in Business Management, 2(1), 165-177.

[63] McClelland, D. C. (1973). Testing for competence rather than for "intelligence.". American Psychologist, 1(1), 1-14.

[64] Spencer, L. M., \& Spencer, S. M. (1993). Competence at work: Models for superior performance. New York: John Wiley \& Sons.

[65] Hoffmann, T. (1999). The meanings of competency. Journal of European Industrial Training, $1(1), 275-285$.

[66] Prastacos, \& Gregory, P. (2012). An application of competencies management in the banking sector. Athens University of Economics and Business, 1(1), 1-15.

[67] Pandey, R., \& Misra, R. K. (2015). Identifying Managerial Competencies in the Indian Banking Sector. Journal of Strategic Human Resource Management, 4(1), 11-14.

[68] Kappagoda, U. W. M. R. (2013). Emotional intelligence of the managers in the banking sector in Sri Lanka. International Journal of Research in Commerce, IT \& Management, 3(6), 153-156.

[69] Nhung, D. T. H. (2019). An empirical analysis of competencies in predicting managerial effectiveness of the sales managers: a Vietnamese banking sector perspective1. Journal of International Economics and Management, 124(12), 24-44.

[70] Jenkin, N., \& Naude, R. (2019). Developing competencies for a just transition of the South African banking sector: Digitalisation. University of Witwatersrand Johannesburg. Centre for researching 
Education and Labor Article, 1(1), 16-20.

[71] Abbasi, F. K., Ali, A., \& Bibi, N. (2018). Analysis of skill gap for business graduates: managerial perspective from banking industry. Education+ Training. 60(4), 354-367.

[72] Onumah, J. M., Gariba, F., Packeys, A., \& Agyapong, R. A. (2012). The banking industry requirements of accounting graduates in Ghana. Accounting in Africa, 12(1), 75-78.

[73] LaBombard, R. J. (2009). Make entry-level hiring an asset. American Bankers Association. ABA Banking Journal, 101(10), 42-46.

[74] Cicekli, E. (2016). Graduate skills requirements for effective performance in the banking sector. Verslas: teorija ir praktika, 17(4), 317-324.

[75] Folcut, O., \& Folea, V. (2019, September). Skills for The Banking Sector. A Perspective from Romanian Graduate Students. In CBU International Conference Proceedings, 7(1), 88-91.

[76] Fernandez, R. M., \& Weinberg, N. (1997). Sifting and sorting: Personal contacts and hiring in a retail bank. American Sociological Review, 1(1) 883-902.

[77] Asaari, Muhammad Hasmi Abu Hassan., \& Karia, Noorliza (2002). Entry Level Job Seekers' Perceptions and Aspirations : A Case of UUM Graduating Students. Refereed Proceeding, 19(9), 547-554.

[78] Devlin, J. S. and Peterson, Robin T. (1984). Students perceptions of entry level employment goals: An international comparison, Journal of Education for Business, 69(3), 154-158.

[79] Chacko, Harsha (1991). Can you pick out the accountant? Students' interest and career choice. Journal of Education for Business, 66(3), 151-154.

[80] Holland, J.L. (1985). Making vocational choices: A theory of vocational personalities and work environments. 2nd. Editon, Englewood Cliffs, Prentice Hall, New Jersey.

[81] Keehan, S.A. (1985). Graduate Recruitment : How graduates select companies - A note. Personnel Review, 1(1), 12-14.

[82] Keerthy, T. R., \& Biju, M. K. (2016). Competency Gap Analysis Among the Employees of Private Sector Banks-A Study with Special Reference to Ernakulam District. Consortia, 3(1), 54-58.

[83] Patil, J., \& Masthan, D. (2014). Competency Mapping of Bank Managers-An Empirical Study. International Journal \& Magazine of Engineering, Technology, Management and Research, 1(8), 01-06.

[84] Nithyavathi, M. K., \& Radha, P. (2014). Research Paper Management Job Competency of Bank Employees in India (With Special Reference to Coimbatore District). Management, 3(2), 13-18.

[85] Bresfelean, V. P., Veres, O., \& Bologa, C. (2010). Competencies and online recruiting for banking occupations. Proceedings of the 2010 international conference on Communication and management in technological innovation and academic globalization. World Scientific and Engineering Academy and Society (WSEAS), 1(1), 117-122.

[86] Jain, V. (2010). Survival skills of business management graduates: A study with reference to retail and banking. Far East Journal of Psychology and Business, 1(4), 59-77.

[87] Bowden, J. A. (2004). Capabilities-driven curriculum design. Effective learning and teaching in engineering, 1(1), 36-47.

[88] Chew, K. S. (2005). An investigation of the English language skills used by new entrants in banks in Hong Kong. English for Specific Purposes, 24(4), 423-435.

[89] Rahayu, S., \& Anna, Y. D. (2013). Soft skills attribute analysis in accounting degree for banking. International Journal of Business, Economics and Law, 2(1), 115-120.

[90] Velasco, M. S. (2012). More than just good grades: candidates' perceptions about the skills and attributes employers seek in new graduates. Journal of Business Economics and 
Management, 13(3), 499-517.

[91] Badmapriya, M., \& Harihara Sudhan, R. I. (2012). Survival Skills of Business Management Professionals: A Study with Reference to Banking Sector. In Conference Proceedings of International Conference on Synchronizing Management Theories and Business Practices Challenges Ahead, Annamalai University, Chidambaram,1(1), 4-8.

[92] Serrano, A. C. (2019). Employability Indices of Business Graduates in the Banking Industry. International Journal of Business Marketing and Management (IJBMM), 4(12), 14-25.

[93] Ting, S. K. T., \& Ying, C. Y. (2012). Business graduates' competencies in the eyes of employers: An exploratory study in Malaysia. World Review of Business Research, 2(2), 176-190.

[94] Hesketh, B., \& McLachlan, K. (1991). Career compromise and adjustment among graduates in the banking industry. British Journal of Guidance \& Counselling, 19(2), 191-208.

[95] Aithal P. S, Shailashree V. T., Suresh Kumar P. M., (2015) A New ABCD Technique to Analyze Business Models \& Concepts. International Journal of Management, IT and Engineering (IJMIE), 5(4), 409 - 423.

[96] Neckerman, K. M., \& Fernandez, R. M. (2003). Keeping a job: Network hiring and turnover in a retail bank. Research in the Sociology of Organizations, 20(1), 299-318.

[97] Shenoy, Varun and Aithal, P. S., (2018). Professional Skills Table for Job Seeking Campus Graduates. Proceedings of national Conference on Education and Empowerment: Challenges for Social Science, IT, and Management, Srinivas Publications, ISBN-978-81-938040-7-0, pp-45-49.

[98] Shenoy, V., \& Aithal, P. S. (2017). A New Box Framework for E-Campus Interview Training. International Journal of Applied Engineering and Management Letters (IJAEML), 1(2), $17-26$. 